REVIEW OF HISTORICAL SCIENCES 2018, VOL. XVII, NO. 3

http://dx.doi.org/10.18778/1644-857X.17.03.08

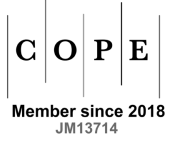

ARIEl ORZEŁEK

Maria Curie SkLOdowsKa University in Lublin*

\title{
The journalistic reaction to the first edition of The History of Stupidity in Poland The historiographic pamphlets by Aleksander Bocheński
}

Summary. The History of Stupidity in Poland. The historiographic pamphlets [Dzieje głupoty w Polsce. Pamflety dziejopisarskie] was the most important publication by Aleksander Bocheński. The book was also one of the most representative reflections on the post-war trend of political realism in Poland. The journalistic reaction to the first edition of the book in the forties of the $20^{\text {th }}$ century proved that the theses included in it were highly unpopular. The author's criticism of insurrection trends in Polish politics met with opposition from Marxists as well as non-party intellectuals, both at home and abroad. Although motives of Bocheński's concepts were usually understood, they were rejected as they served communists, were contrary to Marxist doctrine or had no moral foundations. Those opinions constitute an important contribution to the views of Polish intelligentsia on political realism at the beginnings of the Polish People's Republic.

Keywords: Aleksander Bocheński, historiography, journalism, political realism.

he History of Stupidity in Poland. The historiographic
pamphlets [Dzieje głupoty w Polsce. Pamflety dziejopisarskie]
by Aleksander Bocheński was first published in mid-1947. The book is one of the most representative examples of a realistic view on the history of our country presented from Polish political thought's point of view. Still, the publication, apart from reflections on the history of Poland of the $18^{\text {th }}$ and $19^{\text {th }}$ century and the criticism of historians and journalists propagating harmful, according to Bocheński, political opinions, is a clear reference to the present

${ }^{*}$ Faculty of Humanities, Institute of History, Department of Modern History / Wydział Humanistyczny, Instytut Historii, Zakład Historii Najnowszej, e-mail: ariel.k.orzelek@, gmail.com. 
day. The book was the propaganda tool that was used to redefine a widespread negation of an idea of a settlement with our eastern neighbour. The book was written in the years of World War $\mathrm{II}^{1}$ and was influenced by the author's conviction that the former Polish policy had suffered a total defeat and that it would be Moscow to determine the future of the Polish nation ${ }^{2}$.

It should be added that although in 1939 Bocheński strongly supported the anti-German foreign policy of Józef Beck ${ }^{3}$, a few years earlier, in the interwar period, he was the spokesperson for the 'Polish superpower'. Then, he supported the idea of the Promethean vision that required friendly relations with Germany and preventive aggression against the Soviet Union ${ }^{4}$. Even after the outbreak of the war, he advocated an agreement with the Third Reich that was to put an end to the repression that was devastating the Polish nation. Yet, the victories of the Red Army, the conviction that western allies would leave Polish lands in Józef Stalin's hands, prompted him, around 1943, to reflect on the need to reconcile Polish intelligentsia with Polish and Soviet communists ${ }^{5}$. Already in the spring of 1945, in Cracow, as the head of a conservative group of intellectuals, he talked to Jerzy Borejsza about the creation of a political group focused around Catholic periodical that would affirm the post-Yalta reality. The concept coincided with Bolesław Piasecki's initiative and was subordinated to it ${ }^{6}$.

${ }^{1}$ A letter of Aleksander Bocheński, October 20, 1943, Archiwum Państwowe w Lublinie / The State Archives in Lublin [hereinafter: APL], Archiwum Łosiow $z$ Niemiec / The Archives of the Łoś family of Germany [hereinafter: AŁN], ref. code 463, sheet 10; A letter of Aleksander Bocheński to Stanisław Łoś, Ponikwa, November 10, 1943, ibidem, sheet 11 ; Nie widze wzrostu racjonalnych postaw... $Z$ Aleksandrem Bocheńskim w 85-lecie urodzin rozmawia Karol Pastuszewski, 'Kierunki' 1989, No. 33, p. 7.

${ }^{2}$ A. Bocheński, Dzieje głupoty $w$ Polsce. Pamflety dziejopisarskie, Warszawa 1947.

${ }^{3}$ Idem, Zygzakiem przez prase. Prasa polska po hańbie czeskiej, 'Polityka' 1939, No. 6, p. 8; idem, 'Amocklauf', 'Polityka' 1939, No. 15, p. 1.

${ }^{4}$ Idem, O imperialiźmie, o Skiwskim i o sprawie żydowskiej, 'Polityka' 1938, No. 9 , p. 3 .

${ }^{5}$ Idem, Wędrówki po dziejach przemysłu polskiego, part 2, Warszawa 1969, p. 256; Motywy i postawy [Aleksander Bocheński's statement], 'Kierunki' 1970, No. 48 , p. 8.

${ }^{6}$ R. Mozgol, Ryzykowna gra. Jak Aleksander Bocheński przyczynił się do powstania Dziś i Jutro, 'Biuletyn Instytutu Pamięci Narodowej' 2007, No. 4, pp. 84-92; 'My encounter with Bolesław Piasecki - an interview by Jan Engelgard with Aleksander Bocheński', Archiwum Katolickiego Stowarzyszenia Civitas Christiana / The Archives of the Civitas Christiana Catholic Association [hereinafter: 
The History of Stupidity in Poland, most comprehensive and most important public commentary of Bocheński in the years 1945-1956, was not approved of by the circles of the 'Dziś i Jutro' and, thanks to Stefan Kisielewski's help, was published by the 'Panteon' instead ${ }^{7}$. The followers of Piasecki, many of whom were former partisans of the Striking Cadre Battalions of the National Confederation, perceived it as an attack on the meaning of their own sacrifices ${ }^{8}$. Perhaps it influenced that part of the group that was associated with Piasecki after the war. Its representative, Andrzej Micewski, wrote that The pamphlets... had a significant impact on young activists of the 'Dziś i Jutro'. Piasecki himself did not want to make the ideology of his movement purely pragmatic as he wanted to give it a strong ideological element ${ }^{10}$. Bocheński mentioned that the leader of the 'Unnamed movement' and his supporters were referring to the insurgent tradition, glorifying the insurrections. They did not want to see the connection between the past and the present, so although they appreciated Bocheński's geopolitical argumentation, they had never allowed the book to be published under their auspices. The publicist finally concluded that Piasecki and his companions were in a way romantics ${ }^{11}$.

The pamphlets were in line with the tendencies that, alongside Bocheński, were most loudly expressed by Edmund Osmańczyk in The Poles' Affairs [Sprawy Polaków] ${ }^{12}$ and Ksawery Pruszyński in The Margrave Wielopolski [Margrabia Wielopolski] ${ }^{13}$. The very article aims to analyse journalistic reactions to the book that illustrate various Polish political circles' assessment of the concept of

AKSCCh], Fonds on Aleksander Bocheński, ref. code I/12, no page numbering; A. Garlicki, $Z$ tajnych archiwów, Warszawa 1993, pp. 25-29.

${ }^{7}$ S. Kisielewski, Bocheńscy i Bocheński, 'Tygodnik Powszechny' 1975, No. 39, p. 12 .

${ }^{8}$ Bocheński disliked the fact that the 'Wawel' group, so close to his heart, was incorporated into the Confederation of the Nation. The establishment of that organisation, the name of which was referring to the perplexing, in his opinion, Bar Confederation, prompted him to write The History of Stupidity... - a book that was to discourage everyone from following bad patterns. O głupocie raz jeszcze. Rozmowa z Aleksandrem Bocheńskim, 'Sztandar Młodych' 1986, No. 90, p. 1.

${ }^{9}$ A. Micewski, Katolicy $w$ potrzasku. Wspomnienia $z$ peryferii polityki, Warszawa 1993, p. 27.

${ }^{10}$ J. Engelgard, Bolesław Piasecki 1939-1956, Warszawa 2015, pp. 157-158.

11 'My encounter with Bolesław...', AKSCCh, Fonds on Aleksander Bocheński, ref. code I/12, no page numbering.

${ }^{12}$ E. Osmańczyk, Sprawy Polaków, Katowice 1946.

${ }^{13}$ K. Pruszyński, Margrabia Wielopolski, Warszawa 1946. 
a Catholic intelligentsia's settlement with communists. Another goal of the article is to present Bocheński's realistic historiographic opinions which were usually referring to the concepts of the Cracow historical school. The Author of the text paid special attention not only to articles that fit into the paradigm of Marxist historiography or whose authors were associated with the laity, but also to the book's reception by the émigré press. The unpublished review by Jan Stanisław Łoś, Bocheński's correspondence with Jerzy Giedroyc and Stanisław Cat-Mackiewicz, who both criticised Bocheński's book, as well as the book's evaluation by the Ministry of Public Security were obtained by the Author thanks to his archival research.

There are three main motifs of the described publication. The first one stems from Bocheński's clear belief in the influence of historians (also defined as researchers) on public opinion and politicians. If historians propagate erroneous political concepts, the nation also accepts them, thus aiming at further defeats - Bocheński claimed. In his opinion, those fatal tendencies were the result of the lack of realistic approach to politics which may be understood as a game of interests influenced by emotional factors that, however, should never be decisive. National politics should, therefore, take into account rational premises and rational account of own as well as foreign might. The belief in the supremacy of political realism in international politics was the second motif of The History of Stupidity... The last one was a description of both above-mentioned motifs in Polish conditions. An analysis of the historians' concepts on the policy of Stanisław August Poniatowski, the history of the Polish cause in the Napoleonic period and, to a lesser extent, in the era of national uprisings, served this end. At the same time, it was an expression of Bocheński's views on the above-mentioned issues. He expressed his conviction that national disasters resulted from Polish leaders' disregard of the principle that the rapprochement of Russia and Prussia (Germany), that always had to be of an anti-Polish character, should be prevented at all costs. It should be added here that Bocheński had already propagated that idea before the war in the 'Bunt Młodych' and the Vilnius 'Słowa'. Nevertheless, as it was mentioned above, he proclaimed the need of the cooperation with Berlin. Yet, The historiographic pamphlets... glorified the concept of the Polish-Russian settlement and criticised the believe in the assistance of western powers. The most important character of the book is King Stanisław August, in 
Bocheński's opinion most intelligent Polish ruler, who was unable to lead the Commonwealth through complicated international circumstances of the last decades of the $18^{\text {th }}$ century because of his countrymen's lack of understanding. In the Napoleonic period the Poles blindly believed Napoleon, primarily due to the creation of the Duchy of Warsaw, the irrational fact that resulted from the brilliant career of that intelligent Corsican. According to the publicist, only Prince Adam Jerzy Czartoryski and his supporters were aware of the fact that already before 1812 the Poles should have supported Tsar Alexander I who wanted to rebuild Poland under his rules in exchange for the support in the fight against the emperor of the French. Even after the Congress of Vienna the truncated Polish Kingdom had broad political perspectives which, however, had been wasted by the November and January uprisings. All this happened, summarised Bocheński, because of the dissemination of the 'stupidity' in the Polish nation the historians should be blamed for. He wrote that in the face of the apologia of the insurrection concepts in the Second Polish Republic the suicidal policy of the Polish government in exile and of the underground at home should come as no surprise to anyone.

However, it should also surprise no one that such concepts were usually criticised and had only a few positive reactions. I would like to discuss those opinions in relation to the three main motifs of the book.

In the 'Dziś i Jutro', Stefan Kiniewicz sharply criticised Bocheński's belief in the historians' influence on public opinion. The reviewer stated that historiography was a reflection of the spirit of the age, not the other way round. Bochenski's argument was also disqualified by the fact that he chose works of rather unpopular historians to exemplify his views ${ }^{14}$. Similarly, Hieronim Pawicki criticised such views in the face of the threat of German revisionism ${ }^{15}$. Stanisław K. Rostworowski, as one of few reviewers, underlined that the author of The historiographic pamphlets was right stating that historians should be objective and, when judging decisions of politicians, they should follow the criterion of whether they helped to raise the community in the international hierarchy. He underlined that teaching the nation of political thinking was basic condition of its power which was particularly important

${ }^{14}$ S. Kieniewicz, Nowy sad nad historia, 'Dziś i Jutro' 1947, No. 25, pp. 1-2.

${ }^{15}$ H. Pawicki, [a letter to the editors], 'Dziś i Jutro' 1947, No. 28, p. 12. 
when the geographical location of Poland was taken into account ${ }^{16}$. Similarly, Jan Meysztowicz pointed out that the erroneous, in his opinion, policy of the Polish underground during the war with its most important decision, that is the beginning of the Warsaw Uprising, was greatly influenced by historiographers ${ }^{17}$.

Pawel Jasienica also questioned the thesis of the historians' influence on wrong decisions. He pointed out that such decisions had been also made before the $19^{\text {th }}$ century when many prominent political writers had been working in the Polish-Lithuanian Commonwealth. He considered the naivety of Polish historians, which he did not deny, to be the actual cause of the fall of the Polish Republic and of subsequent national defeats resulting from the lack of strong central authority, the fact that deprived elites from art of political thinking. He also polemicized with the thesis that the old Polish factiousness and anarchy, responsible for the partitions, had no impact on Polish mentality of the $19^{\text {th }}$ century. According to the reviewer, Bocheński disregarded the influence of mass opinion on actions undertaken by politicians. This was evidenced by the policy of King Stanisław August who failed to carry out his plans because of the resistance of masses that influenced the state policy. Thus, Jasienica believed that the book was not about the 'stupidity' but about the lack of political realism, the more that those to whom Bocheński attributed the stupidity, oftentimes, in other places, presented very logical theses ${ }^{18}$. Irena Pannenkowa, in turn, criticised Bocheński in the 'Tygodnik Warszawski' for his objection to the romanticism in historiography. She wrote about his attitude before 1939: "had not he, at that time, "shown off" himself? Had not he "independently" and "mighty" "led astray" there a little?"19.

In the 'Kuźnica', Jan Szczepański claimed that Bocheński's book was to prove that the Poles were a politically 'stupid' nation because of the disastrous influence of the 'stupidity' of their historians. He correctly analysed Bocheński's way of thinking as he defined the 'stupidity' as not observing and not taking advantage of international business conditions. He did, however, question the

${ }^{16}$ S.K. Rostworowski, O szkołę politycznego myślenia, 'Dziś i Jutro' 1947, No. 28, pp. 3-4.

${ }^{17}$ J. Meysztowicz, Jeszcze 'Dzieje głupoty', 'Dziś i Jutro' 1947, No. 22, p. 12.

${ }^{18}$ P. Jasienica, Cień Machiawela, 'Tygodnik Powszechny' 1947, No. 31, pp. 6-7.

${ }^{19}$ I. Pannenkowa, Mentorzy, 'Tygodnik Warszawski’ 1947, No. 49, p. 4. 
thesis that historians had competences and the possibility to influence politics. The Poles were to synonymously treat history and politics and to identify historians with leaders. Szczepański admitted that many historiographers were poor politicians because they did not have access to data used by professional politicians ${ }^{20}$.

Władysław Dziewanowski in the 'Teki Historyczne' discussed Bocheński's arguments much calmer. He noticed that Bocheński's book was determined by the need of historical truth that would be free from distorting conditions or national needs ${ }^{21}$. Stanisław Cat-Mackiewicz, in his letter to Bocheński, accused the latter of displaying insufficiently the influence of the 'fools' (e.g. Messianists) on scholars, that is historians. Cat asserted that from time to time Polish realism had to proclaim stupid slogans to please the society. According to him, Bocheński overestimated the impact of Jędrzej Giertych and Michał Bobrzyński ${ }^{22}$.

The unpublished review by Stanisław Łoś differs from the above-mentioned texts. Its author found it harmful for Poland to yield to the public opinion's will and to have no real school of political thinking. According to Łoś, politicians in Poland lacked knowledge and experience, similarly to those who claimed rights to create political dogmas. It was the real origin, unillustrated by the publication, of the 'Polish stupidity'. National movements and complexes were the result of such a state of affairs. Yet, he agreed with The pamphlets that: 'it is also true that Polish historiography usually absolved a failure to look at the results in accordance with the precepts of the 'virtue', glorifying people who obeyed those precepts. When future generations "sat crying to read the book of errors" they showed a maternal heart to those who were wandering. And finally, when the Pole desired to build in the hearts of his compatriots a monument more durable than bronze,

${ }^{20}$ J. Szczepański, Czy naprawde winni historycy?, 'Kuźnica' 1948, No. 17, p. 7.

${ }^{21}$ W. Dziewanowski, O 'Dziejach głupoty w Polsce', 'Teki Historyczne' 1948, vol. II, No. 2, pp. 69-79.

${ }^{22}$ A letter of Stanisław Cat-Mackiewicz to Aleksander Bocheński, May 15, 1948, Archiwum Instytutu Pamięci Narodowej w Warszawie / The Archives of the Institute of National Remembrance in Warsaw [hereinafter: AIPN], ref. code IPN BU 0648/74/1, sheets 142-143. Bocheński, in his reply to that letter, indicated that he wanted, above all, to emphasise the negative impact of the propaganda of the given views, not the intentions of their authors. [A letter of Aleksander Bocheński to Stanisław Cat-Mackiewicz, Cracow, May 27, 1948] S. Cat-Mackiewicz, Wunderkind. Rzecz o Adolfie Bocheńskim, Kraków 2017, pp. 213-214. 
to achieve the goal he only needed to associate his name with any of great national catastrophes. The history took good intentions for merits' ${ }^{23}$.

Bocheński responded to some of the reviewers'theses, underlining that he was the victim of a misunderstanding. He deliberately focused on authors of synthetic and journalistic works as their texts had a greater impact on the society than monographs. In other words, as Szczepański wrote, he criticised those historiographers who dealt with politics but only if their policy was wrong. According to him, though, historical analogies used by historians strongly influenced the process of political decision-making. It was especially typical of Poland where the nation had been deprived of outstanding, professional decision-makers for two centuries ${ }^{24}$. Bocheński's intentions were well understood by the author of a very flattering review published in the 'Odra', Kazimierz Koźniewski. He pointed out that the publicist transferred his rage at mistakes of Polish politics during the World War II, the reasons of which he saw in the upbringing of the nation by historians-romantics, to the entire insurrectionary tradition of Polish historiography ${ }^{25}$.

Bocheński based his reflections on political realism. It should be added that he defined it as rational, deprived of emotional influences, analysis of reality from which it was possible to draw conclusions on the public sphere. Everything had to be real: the assessment of situation, goals, means and methods of operation as well as the limit of compromise. Bocheński's political realism does not underestimate the influence of emotional factors on politics but it tries to be resistant to it. At the same time, the publicist recognises the importance of morality in politics, although he is aware of the conflict between the morality and actions undertaken to achieve political advantage. The latter, however, usually results from the adoption of an idealistic goal, such as national interest ${ }^{26}$.

23 “'Dzieje głupoty w Polsce” by A. Bocheński', APL, AŁN, ref. code 484, sheets $2-5$.

${ }^{24}$ A. Bocheński, W sprawie 'Dziejów głupoty', 'Kuźnica' 1948, No. 21, p. 11. According to Włodzimierz Dworzaczek, Bocheński’s response was excellent. A letter of Włodzimierz Dworzaczek to Aleksander Bocheński, Poznań, June 16, 1948, AIPN, ref. code IPN BU 0648/74/1, sheet 171.

${ }^{25}$ K. Koźniewski, Na marginesie "Dziejów głupoty w Polsce", 'Odra' 1947, No. 43-44, pp. 6-7.

${ }^{26}$ See P. Kimla, Historycy-politycy jako źródło realizmu politycznego. Tukidydes - Polibiusz - Machiavelli, Kraków 2009; idem, Etyka w realizmie politycznym, 'Czasopismo Prawno-Historyczne' 2014, vol. LXVI, issue 2, pp. 303-314; idem, 
Bocheński's political realism, visible in The History of Stupidity..., challenged the entire Polish romantic-insurrection tradition. Thus, it should come as no surprise that it was also widely criticised. That 'passionate apostle of political realism' ${ }^{27}$, as Stefan Kisielewski described Bocheński, was considered, however, a serious opponent able to violate the insurgent myth. Although Andrzej Micewski admitted that 'the Cracow realism of the historical school is closer to me than all historical and political romantics', he also wrote: 'Certainly, without bards of the $19^{\text {th }}$ century and later romantics, Poland would not exist. But because of our armed uprisings, it has been weak for two centuries'28. 'Kisiel' added that the book was to be 'shouted down' by 'formalistic, pedantic historians', covered with indifference and reluctance of its irritated recipients ${ }^{29}$. At the same time, it was a 'necessary and healthy relief for insurgent mysticism, the only effective relief as it was politically unsuspected and came from the author that had nothing to do with the journalism which was trying to use few slogans to deal with the ideology of blood and sacrifice' ${ }^{30}$.

In the 'Dziś i Jutro' Hieronim Pawicki accused Bocheński of not having broadened his historical, sociological, philosophical and methodological considerations. He opposed his political realism to 'historical realism'31. Yet, Bocheński's rationalism was most severely attacked by Jerzy Braun and Pawel Jasienica. For both of them, the author of The pamphlets... was a neo-positivist follower of the principle of 'no more blood', disregarding the significance of such issues as statistics of victims, hecatomb of blood or logic of national

Realistyczne krytyki moralizatorstwa $w$ polityce, [in:] Moralność i władza jako kategorie myśli politycznej, eds J. Justyński, A. Madeja, Warszawa 2011, pp. 13-22; P. Kimla, Realizm polityczny a Polska, [in:] Między sercem a rozumem. Romantyzm i realizm w polskiej myśli politycznej, eds A. Citkowska-Kimla, P. Kimla, E. Antipow, K. Konik, Kraków 2017, pp. 41-64; H.J. Morgenthau, Polityka między narodami. Walka o potęge i pokój, Warszawa 2010.

${ }^{27}$ S. Kisielewski, Pod włos... Znowu diabet, 'Tygodnik Powszechny' 1946, No. 49 , p. 12.

${ }^{28}$ A. Micewski, Dziennik idacego samotnie (czerwiec 1993 - wrzesień 1998), Warszawa 1998, p. 53.

${ }^{29}$ S. Kisielewski, Gwoździe w mózgu. Świąteczna karuzela, 'Tygodnik Powszechny’ 1959, No. 52, p. 12; idem, Bocheńscy i Bocheński, 'Tygodnik Powszechny' 1975, No. 39, p. 12; idem, Trochę historii, [in:] idem, Felietony, vol. I (Rzeczy małe), Warszawa 2013, p. 276; idem, Porzadek stary już się wali, [in:] idem, Felietony..., p. 330.

${ }^{30}$ Idem, Z literackiego lamusa, Kraków 1979, p. 28.

${ }^{31}$ H. Pawicki, op. cit., p. 12. 
honour ${ }^{32}$. Braun admitted that Bocheński 'distinguishes aimless heroism for the lost gesture from conscious heroism in the service of rational political idea or strategic concept ${ }^{\prime 3}$. Still, the publicists criticised the book for propagating the idea of politics as a brutal struggle as well as for resigning from moral issues, both facts that brought everything to moderate, conservative Machiavellianism. Bocheński was not supposed to be a supporter of violence or crime but of nationalism and imperialism, two things the pre-partition Republic of Poland was not able to achieve ${ }^{34}$. As he postulated the principle of attacking a weaker neighbour, he set himself apart from contemporary tendencies of peaceful regulation of the world and he separated politics from Christian morality. Braun wrote: 'he wants to reconcile his moderate Machiavellianism with Catholicism (he is, in fact, a declared representative of a Catholic group). But such a synthesis of good and evil cannot be realised'35. The reviewer pointed out that Gorski's thesis, criticised by Bocheński, that morality prevailed over strength was reflected in history in the victory of Rome over Carthage or Greece over Persia. The publicist of the 'Tygodnik Warszawski' preferred moral law to logic, pointing out that the first was actually winning in politics. Quoting Mahatma Gandhi, he claimed that the greatness of the nation should serve to raise humanity but for Bocheński it was a goal itself. As it seems, the author of the review did not go beyond the nineteenth-century idealism as he did not notice that those who were able to dominate in moral issues could also overcome their potential ${ }^{36}$. Jasienica had similar views as, according to him, Bocheński condemned all who were guided in politics by a soberly understood interest, not by the desire to have morally good attitude ${ }^{37}$.

32 J. Braun, Bronie romantyzmu, 'Tygodnik Warszawski' 1948, No. 7, p. 1; P. Jasienica, op. cit., pp. 6-7.

${ }^{33}$ J. Braun, Katolicyzm a machiawelizm, 'Tygodnik Warszawski' 1948, No. 12, p. 6.

${ }^{34}$ The phenomenon was criticised by Bocheński and his brother Adolf in their first book. A. Bocheński, A.M. Bocheński, Tendencje samobójcze narodu polskiego, Lwów 1925. In his reply, Bocheński wrote that he was not opposed to the idea of an armed struggle but of a struggle that was undertaken in unfavourable circumstances. Many times he tried to prove that it would be better to fight well-prepared than to participate in 'movements our ancestors had limited themselves to'. A. Bocheński, List do redakcji, 'Tygodnik Warszawski’ 1948, No. 9, p. 8.

${ }^{35}$ J. Braun, Katolicyzm a machiawelizm..., p. 1.

${ }^{36}$ Ibidem, p. 6.

${ }^{37}$ P. Jasienica, op. cit., pp. 6-7. 
Marxist criticism, represented by Józef Dutkiewicz and Celina Bobinska, underlined that there was a contradiction of Bocheński's realism with the traditions of revolutionary and national liberation struggle. Bocheński's realism was to be short-sighted because, in the opinion of the reviewers, the uprisings had been successful and had led to the contemporary People's Poland. Bobinsska considered it harmful that Bocheński's analysis was, in fact, historical argumentation for the Polish-Soviet 'alliance ${ }^{38}$. Thus, in the Ministry of Public Security's opinion, the book by Bocheński was anti-Soviet ${ }^{39}$.

According to Irena Pannenkowa, Bocheński's and K. Pruszyński's thesis that only effective politicians could be the great ones, was wrong. The criterion of political strength was to be, in fact, unpopular among the Poles. Therefore: 'The fact that the theses and arguments presented in the books by Bocheński and Pruszyński were criticised and repelled by writers of both Catholic camp (Kieniewicz, Jasienica) and Marxist one (Bobińska), proves, among other things, that they have no support in the broad masses of society. This should give food for thought for both writers in the future $^{40}$. It should be added that both aforementioned publicists did not consider the popularity of their views to be a measure of their value, though.

38 J. Dutkiewicz, Aleksander Bocheński: Dzieje głupoty w Polsce. Wyd. Panteon, Warszawa 1947, str. 330, 'Myś1 Współczesna' 1948, No. 4, pp. 132-135; C. Bobińska, Tradycje i teraźniejszość, 'Nowe Drogi' 1947, No. 4, pp. 72-91. Elsewhere, in 1950, Bobińska wrote, criticising in particular Adam Skałkowski's work on Aleksander Wielopolski as well as certain trends in Polish historiography: 'the raison d'état was to be a policy of compromise with tsarist Russia. Here we have the Cracow conservatism as a "scientific base" for the promotion of the National Democratic sanctity, all in the sauce of an eternal and imperishable Polish-German conflict and the usual need of "reconciliation with Russia", that is with tsarism. A few years ago the so-called "Catholic neo-positivists" put forward this National Democratic idea, proving that the People's Poland is... the heir of Wielopolski and Dmowski. At the cost of discrediting the revolutionary alliance of the People's Poland with the revolutionary Soviet Union, they wanted to "reconcile" the reactionary bourgeoisie with the popular democracy'. Eadem, O przełom $w$ nauce historycznej. Na marginesie narady historyków-marksistów, 'Nowa Kultura' 1950, No. 2, p. 3.

39 'The figure of Aleksander Bocheński', AIPN, ref. code IPN BU 0648/74/1, sheet 206.

${ }^{40}$ I. Pannenkowa, Mentorzy..., p. 4. Pannenkowa had developed her critic of political realism in the assessment of the past already in 1946. Eadem, Czy nie za wiele pesymizmu?, 'Tygodnik Warszawski’ 1946, No. 34, p. 2. 
Bocheński's book was emotionally described in the 'Gazeta Ludowa' by 'dr Wacław Reguła', that is former senator, Wojciech Rostworowski. He accused the publication of primitivism, disrespect and insensitivity to the issues of 'honour and conscience', and Bocheński himself - of the 'immorality' so surprising to a Catholic activist. Bocheński, in his opinion, saw in the tragic events of Poland only the 'stupidity ${ }^{31}$.

Jan Ulatowski wrote in the 'Kultura' that The History of Stupidity... denigrated the idea of Polish statehood and disregarded geopolitics. According to him, the regulations of the latter were to require active manifestation of national laws in order to preserve own identity and to build even false myths. According to Ulatowski, should the Poles have accepted Bocheński's theses, they could have not taken advantage of the opportunities that a possible World War III would have brought to them ${ }^{42}$. Władysław Dziewanowski in the 'Teki Historyczne' analysed the problem more thoroughly as he regarded the apologia of an agreement as the nation's primacy over state, the fact that was certain to cause negative political consequences ${ }^{43}$. Wiktor Weintraub in the London 'Wiadomości' as well as Wojciech Wasiutyński in the 'Myśl Polska' agreed, in turn, that Bocheński was more of the heir to the Cracow school of history than to Dmowski, as from the first he had inherited the method of viewing Poland's relations with neighbours, and from the other - orientation to Russia. In addition, according to Weintraub, the publicist was to ignore socio-economic factors in order to demonstrate the supremacy of real politics in the game of great powers. Wasiutyński and other emigrant national magazine, 'Placówka', argued that realists such as Bocheński would soon be of no need to the Soviets, as Moscow had in Polish communists ideological, not opportunist, ally. The Nationalists and Weintraub did not accuse Bocheński of opportunism but of a completely wrong judgement of the situation ${ }^{44}$. In the 'Odra' Koźniewski, in turn, wrote that The

${ }^{41}$ W. Reguła [W. Rostworowski], Dzieje głupoty w Polsce, 'Gazeta Ludowa' 1947, No. 180 , p. 5.

${ }^{42}$ J. Ulatow ski, Dzieje głupoty w Polsce, 'Kultura' 1947, No. 2-3, pp. 151-157.

${ }^{43}$ W. Dziewanowski, O 'Dziejach głupoty $w$ Polsce', 'Teki Historyczne' 1948, vol. II, No. 2, pp. 69-79.

${ }^{44}$ W. Weintraub, Jak być mądrym wobec Rosji, 'Wiadomości' 1947, No. 31, p. 1; W. Wasiutyński, Neougodowiec, 'Myśl Polska' 1948, No. 7, p. 9; (m), Czy historycy sa odpowiedzialni za nasza politykę, 'Placówka' 1948, No. 3, p. 3. 
History of Stupidity had the universal meaning and, therefore, he advised against giving Bocheński's book as an example of contemporary orientation towards Russia ${ }^{45}$.

Finally, Adam Michnik accused The History of Stupidity of an erroneous conception as well as of opportunism and treason, calling it a 'manifesto of betrayal'. The monograph was to clearly define Bocheński's path as a 'realist', cooperating with communists. At the same time, the title of Michnik's publication, From the History of Honour in Poland [ $\mathrm{Z}$ dziejów honoru w Polsce], referred to Bocheński's most famous book ${ }^{46}$.

Certainly, most disliked fragment of Bocheński's book was the lecture on Polish history from the era of Stanisław August to the present day. According to Jan Nepomucen Miller, the theses were so broad and provocative that they did not result from an in-depth source research but from the 'political metaphysics'. The reviewer acknowledged the need of an 'alliance' with the Soviet Union but he accused the publicist that while criticising the history of the struggle with the tsarist Russia, he made the Poles disregard their own past. He attributed to him the desire to whitewash the tsarist regime at the expense of a greater criticism of the 'foolishness' of his countrymen. In Miller's opinion it was right to criticise the Bar Confederation, the policy of the Great Diet and the insurrectionist tradition but one should not glorify Catherine II or Nikolai Repnin instead. According to the reviewer, the tsarina was in Bocheński's eyes 'almost a mother of mercy for Poland tormented by the Poles'. At the same time Bocheński was inconsistent - although he found it necessary to fight systemic errors, the author of The pamphlets... criticised the Great Diet. Miller was also uncertain whether the policy of preventing the fight with Russia was the best one in the $18^{\text {th }}$ century. In his opinion, it has not been decisively proved that Russia did not want the Republic's partitions. In the opinion of the reviewer, Bocheński was way too confident in constructing his theses as he did not support them by substantive research, thus becoming a 'ministerial spokesman' and 'propagandist'. Yet, his reflection was necessary and interesting and, if he had resigned from the 'theological' and 'metaphysical' approach, he could become an

${ }^{45}$ K. Koźniewski, Na marginesie "Dziejów..., pp. 6-7.

${ }^{46}$ A. Michnik, $Z$ dziejów honoru $w$ Polsce. Wypisy więzienne, Paryż 1985, pp. 159, 169-170, 190-191. 
excellent historian ${ }^{47}$. The 'Gazeta Ludowa' was more than pleased to quote those critical considerations ${ }^{48}$.

Kieniewicz believed that sometimes the 'stupidity' criticised by Bocheński was identical with the raison d'état. He doubted that Russia disliked the idea of the Republic of Poland's partition ${ }^{49}$. Also in Dziewanowski's opinion the pro-Russian policy was risky - according to him, it was Russia's guilt that all attempts aiming at settlement has always failed so far. It is difficult to agree with the opinion that the publicist disregarded the growth of the strength of neighbours as a factor influencing Poland's fall (Bocheński believed in the principle of political relativism that the power of the state depends primarily on the potential of its neighbouring countries $)^{50}$. According to Ulatowski, in turn, the liberum veto, also criticised by Bocheński, was the manifestation of Polish instinct of freedom. Similarly, he believed that Polish uprisings had been constantly 'electrifying the nation' and contributed to the fact that independence was regained ${ }^{51}$. Bocheński's narrative was harshly criticised by the 'Placówka' that referred to the interwar past of the author of the publication and the fact that after the World War II Bocheński became an apologist for the Curzon line. The monthly also recalled his and Giedroyc's group's 'super-power' programme as well as the criticism of the provisions of the Treaty of Riga that deprived Poland of many of its borderline areas. The book, tinted with red ink over time, was to be a reaction to the defeat of 1939 and a result of a critical review of 'pro-Piłsudski's slogans ${ }^{52}$.

Dutkiewicz was shocked by Bocheński's conclusions which had to lead to the criticism of the revolution of 1905 and the praise of the Poles' participation in the Russian Duma. He was also outraged by the fact that Edward Dembowski was described as a 'madman's3.

47 J.N. Miller, 'Tym gorzej dla faktów!', 'Warszawa' 1947, No. 10, p. 2.

${ }^{48}$ Przeglad prasy literackiej. Historia, opozycja, postep, 'Gazeta Ludowa' 1947, No. 256, p. 5.

${ }^{49}$ S. Kieniewicz, op. cit., pp. 1-2.

${ }^{50}$ W. Dziewanowski, op. cit., pp. 69-79.

${ }^{51} \mathrm{~J}$. Ulatowski, op. cit., pp. 151-157.

$52(\mathrm{~m})$, op. cit., p. 3. In his letter to Bocheński, Jerzy Giedroyc found the text in question shocking. Still, according to the editor of the 'Kultura', The History of Stupidity... was a 'terrible' book. A letter of Jerzy Giedroyc to Aleksander Bocheński, March 11, 1948, AIPN, ref. code IPN BU 0648/74/1, sheet 107; A letter of Jerzy Giedroyc to Aleksander Bocheński, July 19, 1948, ibidem, sheets 168-169.

${ }^{53}$ J. Dutkiewicz, op. cit., pp. 132-135. 
In Bobińska's opinion, in turn, historical views of Bocheński were simply 'reactionary's4.

Stanisław Stomma referred to The History of Stupidity... in his famous article titled An Access to modern Poland [Dostęp do Polski współczesnej]. He tried to find historical argumentation for the programme of an agreement with the Soviet Union during the October changes ${ }^{55}$. Characteristically, Irena Pannenkowa once again reacted negatively to the concept as she wrote that Poland should 'go alongside Russia' in the period not postulated by Bocheński, that is during the two world wars ${ }^{56}$. She also believed that Bocheński was inconsistent - he criticised the uprisings but at the same time he positively portrayed Józef Piłsudski, the apologist for the insurrection tradition ${ }^{57}$.

The re-edition of the book in 1984 provoked a discussion in the 'Rzeczywistość'. Hubert Kozłowski underlined the validity of criticism of the national uprisings' irrationality and Bocheński's conviction that the raison d'état should strive for a national development. He repeated after Bocheński that the nation should be raised in the spirit of realism and reason ${ }^{58}$. Piotr Wagiel responded that the nation had always respected insurgents, not realists, and that fact should become a decisive argument in the dispute ${ }^{59}$.

Bocheński did not analyse the above-mentioned polemics in details. He underlined, however, that he had repeatedly demanded respect for the fighting and the deceased, also in the name of national interests and rational, patriotic education. His critics wanted to extend that cult to the decision-makers while he was constantly demanding to assess those two groups separately. Finally, he concluded that the book would defend itself with its arguments ${ }^{60}$. The polemics in the 'Rzeczywistość' echoed the disputes of the forties of the $20^{\text {th }}$ century as it was evidenced by the reviews published in

${ }^{54}$ C. Bobińska, Tradycje i teraźniejszość..., pp. 72-91.

${ }^{55}$ S. Stomma, Dostęp do Polski wspótczesnej, 'Przegląd Kulturalny' 1956, No. 43, pp. 6-7.

${ }^{56}$ I. Pannenkowa, Historia mistrzynia życia ale tylko prawdziwa. O racji stanu, ideologii, oraz madrości i głupocie politycznej, 'Przegląd Kulturalny' 1957, No. 12, pp. 1, 8-9.

${ }^{57}$ Eadem, Mentorzy..., pp. 3-4.

${ }^{58}$ H. Kozłowski, Powrót 'Dziejów głupoty', 'Rzeczywistość' 1984, No. 36, pp. 6-7; idem, Rozum przeciwko głupocie, 'Rzeczywistość' 1984, No. 45, pp. 4-5.

${ }^{59}$ P. Wagiel, Podzwonne dla głupoty, 'Rzeczywistość' 1984, No. 41, p. 7.

${ }^{60}$ A. Bocheński, Książka obroni się sama..., 'Rzeczywistość' 1984, No. 45, p. 4. 
the 'Polityka" ${ }^{61}$, the "Tu i teraz's2, the 'Perspektywy' ${ }^{63}$ and the "Nowe Ksiażki ${ }^{36}$. In the nineties, in turn, one of the reviewers used the term 'The Story of Deafness' to describe readers' reaction to the last issue of Bocheński's book ${ }^{65}$.

The book was not only discussed in review articles but had many references in historiography and journalism, too. Pejorative references to the 'stupidity in Poland' or more often to the 'Polish stupidity' (which was, however, a distortion of the meaning of the statement) appeared in a number of works ${ }^{66}$.

Andrzej F. Grabski noticed that Bocheński referred in his book to the concept of Henryk Barycz who criticised the insurrection and Jagiellonian tradition. He also noted that Marxist criticism of those concepts soon became out of date while Bocheński's theses were incorporated into the historical reflection supported by people ruling the People's Poland ${ }^{67}$.

Yet, one may agree with the opinion expressed in 1970 by Józef Lewandowski that Bocheński's book 'is still one of the most inspirational and thought-provoking books of the last 25 years, [...] Polish political and historiosophical thought would be much poorer without this work ${ }^{68}$. Bocheński criticised wrong decisions, not the sacrifice and bravery of the fighters, and many times he was stressing the need to distinguish between those two categories. Realism was for him a sober evaluation of determinants by the decision-makers. Soldiers, however, or more broadly - the nation, should absolutely listen to orders of their leaders. The thing is, the journalist argued, that such orders should be based on a sober analysis of the international situation. Oftentimes national leaders

${ }^{61}$ A. Mozołowski, Dzieje głupoty nieśmiertelnej, 'Polityka' 1984, No. 44, p. 5.

${ }^{62}$ K. Koźniewski, Zamek, 'Tu i teraz' 1984, No. 37, pp. 1, 9.

${ }^{63}$ J. Koprowski, Zgoda i niezgoda, 'Perspektywy' 1984, No. 39, p. 24.

${ }^{64}$ J. Michalski, Grzechy sprzed lat, 'Nowe Książki' 1984, No. 9, pp. 13-16.

${ }^{65}$ K. Koźniewski, Najnowsze wydanie ksiażki Aleksandra Bocheńskiego znowu przechodzi bez echa. Dzieje głuchoty w Polsce, 'Wiadomości Kulturalne' 1997, No. 2, p. 7.

${ }^{66}$ See Żałosny mit realizmu. $Z$ prof. Andrzejem Nowakiem, historykiem, publicysta rozmawia Marcin Makowski, 'Do Rzeczy' 2017, No. 16, pp. 69-71; R.A. Ziemkiewicz, Złowrogi cień Marszałka, Lublin-Warszawa 2017, p. 224.

${ }^{67}$ A.F. Grabski, Orientacje polskiej myśli historycznej. Studia i rozważania, Warszawa 1972, pp. 39-43; H. Barycz, O nowe drogi historiografii polskiej, 'Nauka i Sztuka' 1946, vol. II, pp. 324-335.

${ }^{68}$ J. Lewandowski, "Dzieje przemysłu" Aleksandra Bocheńskiego, 'Kultura' 1970, No. 9, pp. 131-132. 
- Stanisław August or the Margrave Wielopolski - made right decisions which, however, were sabotaged by the masses raised by the 'cliché patriotism'

According to Kisielewski, Bocheński was planning to write the second part of The History of Stupidity... titled 'The Land of Great Fools' [Kraina wielkich błaznów] with such chapters as: 'Mickiewicz', 'Chopin', 'Osterwa'70. The title may be interpreted in two ways - both as a critique of political reasoning of the Polish nation and an apology of the 'great fools' - the so-called Stańczycy. Bocheński had repeatedly referred to the achievements of the Cracow historical school and its heirs, thus he could have tried to indicate in his book that not the most widespread and dominant traditions but those of the Stanczycy had the indivisible right to be called 'great'.

Nevertheless, Bocheński's book achieved at least one of its goals - it stimulated a discussion on the limits of realism in Polish politics. It was a part of a long-lasting dispute about concepts on the foreign policy which was facing the problem of the loss of the state's independence and efforts to restore $\mathrm{it}^{71}$. The book was published in specific political conditions, thus it tried to convince the readers of the concept of an agreement with communists which, in Bocheński's opinion, was a reference to the traditions of the nineteenth-century positivists such as the Stańczycy or ideological heirs of the Margrave Wielopolski. Bocheński's concepts were condemned by communists, the laity and the independence emigration that was understood by a small group of publicists ideologically related to him.

${ }^{69}$ See A. Bocheński, Rozmyślania krytyczne. Błąd Zbigniewa Florczaka, 'Kierunki' 1956, No. 2, p. 1; idem, Analiza polityczna artykułu Jerzego Łojka, 'Kierunki' 1958, No. 1, p. 7; idem, Drugi artykut o margrabim, 'Kierunki' 1958, No. 11, p. 1.

${ }^{70} \mathrm{~S}$. Kisielewski, Gwoździe w mózgu. Świateczna..., p. 12; idem, Bocheńscy $i$ Bocheński..., p. 12. Reflections on Bocheński taken from the latter text were also quoted in the London 'Wiadomości'. Glosator, Z czasopism krajowych, 'Wiadomości' 1975, No. 50, p. 5. Already in 1948, he wrote to Cat about his project on 'The Land of Great Fools' [Kraina wielkich błaznow]. Yet, he stated that he would not write the book as not to upset 'our small fools'. [A letter of Aleksander Bocheński to Stanisław Cat-Mackiewicz, Kraków, May 27, 1948], S. Cat-Mackiewicz, Wunderkind..., p. 215.

${ }^{71}$ According to Adam Bromke, the dispute between romanticism and realism was constitutive of Polish political thought of last centuries. A. Bromke, Poland's Politics. Idealism vs Realism, Cambridge 1967. 


\section{Bibliography}

\section{Archival sources}

Archiwum Instytutu Pamięci Narodowej w Warszawie [AIPN]

(The Archives of the Institute of National Remembrance in Warsaw) ref. code IPN BU 0648/74/1.

Archiwum Katolickiego Stowarzyszenia Civitas Christiana [AKSCCh]

(The Archives of the Civitas Christiana Catholic Association)

Fonds on Aleksander Bocheński, ref. code I/12.

Archiwum Państwowe w Lublinie [APL]

(The State Archives in Lublin)

Archiwum Łosiów $z$ Niemiec [AŁN] / The Archives of the Łoś family of Germany, ref. code 463, 484.

\section{Printed SOURCes}

Garlicki A., Z tajnych archiwów, Warszawa 1993.

\section{Press}

Bobińska C., O przełom $w$ nauce historycznej. Na marginesie narady historyków-marksistów, 'Nowa Kultura' 1950, No. 2, p. 3.

Bobińska C., Tradycje i teraźniejszość, 'Nowe Drogi' 1947, No. 4, pp. 72-91.

Bocheński A., 'Amocklauf', 'Polityka' 1939, No. 15, p. 1.

Bocheński A., Analiza polityczna artykułu Jerzego Łojka, 'Kierunki' 1958, No. 1, pp. 6-7.

Bocheński A., Drugi artykuł o margrabim, 'Kierunki' 1958, No. 1, pp. 1-2, 5, 7.

Bocheński A., Dzieje głupoty w Polsce. Pamflety dziejopisarskie, Warszawa 1947.

Bocheński A., Książka obroni się sama..., 'Rzeczywistość' 1984, No. 45, p. 4.

Bocheński A., List do redakcji, ‘Tygodnik Warszawski' 1948, No. 9, p. 8.

Bocheński A., Motywy i postawy [Aleksander Bocheński's statement], 'Kierunki' 1970, No. 48, p. 8.

Bocheński A., O imperialiźmie, o Skiwskim i o sprawie żydowskiej, 'Polityka' 1938, No. 9, p. 3.

Bocheński A., Rozmyślania krytyczne. Błąd Zbigniewa Florczaka, 'Kierunki' 1956, No. 2, pp. 1, 12.

Bocheński A., W sprawie 'Dziejów głupoty', 'Kuźnica' 1948, No. 21, p. 11.

Bocheński A., Wędrówki po dziejach przemysłu polskiego, part 2, Warszawa 1969.

Bocheński A., Zygzakiem przez prasę. Prasa polska po hańbie czeskiej, 'Polityka' 1939, No. 6, p. 8.

Bocheński A., Bocheński A.M., Tendencje samobójcze narodu polskiego, Lwów 1925. 
Braun J., Bronię romantyzmu, 'Tygodnik Warszawski’ 1948, No. 7, p. 1.

Braun J., Katolicyzm a machiawelizm, 'Tygodnik Warszawski' 1948, No. 12, pp. 1, 6.

Cat-Mackiewicz S., Wunderkind. Rzecz o Adolfie Bocheńskim, Kraków 2017.

Dutkiewicz J., Aleksander Bocheński: Dzieje głupoty $w$ Polsce. Wyd. Panteon, Warszawa 1947, str. 330, 'Myśl Współczesna' 1948, No. 4, pp. 132-135.

Dziewanowski W., O 'Dziejach głupoty w Polsce', 'Teki Historyczne' 1948, vol. II, No. 2, pp. 69-79.

Glosator, Z czasopism krajowych, 'Wiadomości' 1975, No. 50, p. 5.

Grabski A.F., Orientacje polskiej myśli historycznej. Studia i rozważania, Warszawa 1972.

Jasienica P., Cień Machiawela, 'Tygodnik Powszechny’ 1947, No. 31, pp. 6-7.

Kieniewicz S., Nowy sąd nad historia, 'Dziś i Jutro' 1947, No. 25, pp. 1-2.

Kisielewski S., Bocheńscy i Bocheński, 'Tygodnik Powszechny' 1975, No. 39, p. 12.

Kisielewski S., Felietony, vol. I (Rzeczy małe), Warszawa 2013.

Kisielewski S., Gwoździe w mózgu. Świąteczna karuzela, 'Tygodnik Powszechny’ 1959, No. 52, p. 12.

Kisielewski S., Pod włos... Znowu diabeł, 'Tygodnik Powszechny' 1946, No. 49, p. 12.

Kisielewski S., Z literackiego lamusa, Kraków 1979.

Koprowski J., Zgoda i niezgoda, 'Perspektywy' 1984, No. 39, p. 24.

Kozłowski H., Powrót 'Dziejów głupoty', 'Rzeczywistość' 1984, No. 36, pp. 6-7.

Kozłowski H., Rozum przeciwko głupocie, 'Rzeczywistość' 1984, No. 45, pp. 4-5.

Koźniewski K., Na marginesie "Dziejów głupoty w Polsce", 'Odra' 1947, No. 43-44, pp. 6-7.

Koźniewski K., Najnowsze wydanie książki Aleksandra Bocheńskiego znowu przechodzi bez echa. Dzieje głuchoty $w$ Polsce, 'Wiadomości Kulturalne' 1997, No. 2, p. 7 .

Koźniewski K., Zamek, ‘Tu i teraz’ 1984, No. 37, pp. 1, 9.

Lewandowski J., "Dzieje przemysłu" Aleksandra Bocheńskiego, 'Kultura' 1970, No. 9, pp. 131-135.

(m), Czy historycy sa odpowiedzialni za nasza polityke, 'Placówka' 1948, No. 3, p. 3.

Meysztowicz J., Jeszcze 'Dzieje głupoty', 'Dziś i Jutro' 1947, No. 22, p. 12.

Micewski A., Dziennik idacego samotnie (czerwiec 1993 - wrzesień 1998), Warszawa 1998.

Micewski A., Katolicy $w$ potrzasku. Wspomnienia z peryferii polityki, Warszawa 1993.

Michalski J., Grzechy sprzed lat, 'Nowe Książki’ 1984, No. 9, pp. 13-16.

Michnik A., Z dziejów honoru w Polsce. Wypisy więzienne, Paryż 1985.

Miller J.N., 'Tym gorzej dla faktów!', 'Warszawa' 1947, No. 10, p. 2.

Mozołowski A., Dzieje głupoty nieśmiertelnej, 'Polityka' 1984, No. 44, p. 7. 
Nie widze wzrostu racjonalnych postaw... Z Aleksandrem Bocheńskim $w$ 85-lecie urodzin rozmawia Karol Pastuszewski, 'Kierunki' 1989, No. 33, pp. 1, 7.

O głupocie raz jeszcze. Rozmowa z Aleksandrem Bocheńskim, 'Sztandar Młodych' 1986, No. 90, pp. 1, 3.

Osmańczyk E., Sprawy Polaków, Katowice 1946.

Pannenkowa I., Czy nie za wiele pesymizmu?, 'Tygodnik Warszawski' 1946, No. 34, p. 2.

Pannenkowa I., Historia mistrzynia życia ale tylko prawdziwa. O racji stanu, ideologii, oraz madrości i głupocie politycznej, 'Przegląd Kulturalny' 1957, No. 12, pp. 1, 8-9.

Pannenkowa I., Mentorzy, 'Tygodnik Warszawski' 1947, No. 49, pp. 3-4.

Pawicki H., [a letter to the editors], 'Dziś i Jutro' 1947, No. 28, p. 12.

Pruszyński K., Margrabia Wielopolski, Warszawa 1946.

Przeglad prasy literackiej. Historia, opozycja, postęp, 'Gazeta Ludowa' 1947, No. 256, p. 5.

Reguła W. [Rostworowski W.], Dzieje głupoty w Polsce, 'Gazeta Ludowa' 1947, No. 180 , p. 5.

Rostworowski S.K., O szkołę politycznego myślenia, 'Dziś i Jutro' 1947, No. 28, pp. 3-4.

Stomma S., Dostęp do Polski współczesnej, 'Przegląd Kulturalny' 1956, No. 43, pp. 6-7.

Szczepański J., Czy naprawdę winni historycy?, 'Kuźnica' 1948, No. 17, p. 7.

Ulatowski J., Dzieje głupoty w Polsce, 'Kultura' 1947, No. 2-3, pp. 151-157.

Wasiutyński W., Neougodowiec, 'Myśl Polska' 1948, No. 7, p. 9.

Wagiel P., Podzwonne dla głupoty, 'Rzeczywistość' 1984, No. 41, p. 7.

Weintraub W., Jak być mądrym wobec Rosji, 'Wiadomości' 1947, No. 31, p. 1.

Ziemkiewicz R.A., Złowrogi cień Marszałka, Lublin-Warszawa 2017.

Żałosny mit realizmu. $Z$ prof. Andrzejem Nowakiem, historykiem, publicysta rozmawia Marcin Makowski, 'Do Rzeczy’ 2017, No. 16, pp. 69-71.

\section{Studies}

Barycz H., O nowe drogi historiografii polskiej, 'Nauka i Sztuka' 1946, vol. II, pp. 324-335.

Bromke A., Poland's Politics. Idealism vs Realism, Cambridge 1967.

Engelgard J., Bolesław Piasecki 1939-1956, Warszawa 2015.

Górny M., Przede wszystkim ma być naród. Marksistowskie historiografie w Europie środkowo-wschodniej, Warszawa 2007.

Grabski A.F., Orientacje polskiej myśli historycznej. Studia i rozważania, Warszawa 1972.

Kimla P., Etyka $w$ realizmie politycznym, 'Czasopismo Prawno-Historyczne' 2014, vol. LXVI, issue 2, pp. 303-314. 
Kimla P., Historycy-politycy jako źródło realizmu politycznego. Tukidydes - Polibiusz - Machiavelli, Kraków 2009.

Kimla P., Realistyczne krytyki moralizatorstwa w polityce, [in:] Moralność i władza jako kategorie myśli politycznej, eds J. Justyński, A. Madeja, Warszawa 2011, pp. 41-64.

Kimla P., Realizm polityczny a Polska, [in:] Między sercem a rozumem. Romantyzm $i$ realizm $w$ polskiej myśli politycznej, eds A. Citkowska-Kimla, P. Kimla, E. Antipow, K. Konik, Kraków 2017, pp. 41-64.

Morgenthau H.J., Polityka między narodami. Walka o potegę i pokój, Warszawa 2010.

Mozgol R., Ryzykowna gra. Jak Aleksander Bocheński przyczynił się do powstania Dziś $i$ Jutro, 'Biuletyn Instytutu Pamięci Narodowej’ 2007, No. 4, pp. 84-92.

Stobiecki R., Historiografia PRL. Ani dobra, ani madra, ani piękna... Ale skomplikowana, Warszawa 2007.

ARIEL ORZEŁEK

\title{
Recepcja publicystyczna Dziejów gtupoty w Polsce. Pamfletów dziejopisarskich Aleksandra Bocheńskiego
}

\begin{abstract}
Zieje głupoty $w$ Polsce. Pamflety dziejopisarskie były najważniejszą publikacja Aleksandra Bocheńskiego. Stanowiły także jedną z najbardziej reprezentatywnych refleksji dla powojennego nurtu realizmu politycznego w Polsce. Recepcja publicystyczna pierwszego wydania tej ksiażki w latach czterdziestych XX w. dowodziła niepopularności tez w niej zawartych. Krytyka insurekcyjnych nurtów polityki polskiej dokonana przez publicystę spotykała się ze sprzeciwem zarówno marksistów, bezpartyjnych intelektualistów w kraju, jak i środowisk emigracyjnych. Chociaż zazwyczaj rozumiano motywy koncepcji Bocheńskiego, odrzucano je jako: służace komunistom, sprzeczne $z$ doktryną marksistowską bądź pozbawione fundamentu moralnego. Opinie te stanowia istotny przyczynek zapatrywań polskiej inteligencji na problematykę politycznego realizmu u progu Polski Ludowej.
\end{abstract}

Słowa kluczowe: Aleksander Bocheński, historiografia, publicystyka, realizm polityczny. 